\title{
Corrigendum to "Prevalence of thermoduric bacteria and spores on 10 Midwest dairy farms"1
}

\author{
Kimberly P. Buehner, ${ }^{*}$ Sanjeev Anand, ${ }^{2}$ Gemechis D. Djira,† and Alvaro Garcia* \\ *Midwest Dairy Foods Research Center, Dairy Science Department, South Dakota State University, Brookings 57007 \\ †Department of Mathematics and Statistics, South Dakota State University, Brookings 57007
}

\begin{abstract}
Thermoduric bacteria (TDB), including sporeformers and their spores, can be present in milk and dairy products even after pasteurization. They have the potential to adversely affect the quality and shelf life of products. The objectives of this study were to identify the origin and common species of heat-resistant bacteria occurring during summer and winter on Midwest dairy farms. Bulk tank milk samples were taken from 10 dairy farms located along the South Dakota section of Interstate 29, with herd sizes ranging from 650 to 3,500 lactating dairy cows. Milk samples were profiled for the prevalence of TDB and spore counts (SC). Corn silage samples and swabs of the milking clusters were also taken at the dairies to further profile the potential sources of TDB and SC. The samples were taken 3 times during 2 seasons [winter (January-March) and summer (June-August)] to track seasonal changes in the farm bacterial flora. During winter, the average TDB counts in bulk tank milk were 1.83 log compared with 1.89 $\log$ TDB counts in the summer. The SC was $0.85 \log$ in the winter, which was about half the $1.37 \log \mathrm{SC}$ present in the summer season. Corn silage sampled in winter contained $4.09 \log$ TDB count compared with an increased $5.85 \log$ TDB count during summer sampling. Concentrations of SC in corn silage reached an average of $3.60 \mathrm{log}$ in winter compared with $6.33 \mathrm{log}$ for summer. The seasonal effect was evident with an increase in summer counts across the board for TDB and SC, both in the feed and bulk tank milk samples. Bacillus licheniformis was the predominant species identified in $62.4 \%$ of winter (85 total) and $49.4 \%$ of summer (83 total) samples. Bacillus subtilis made up $9.4 \%$ of the remaining winter isolates, followed by Bacillus sonorensis

\footnotetext{
Received May 8, 2014.

Accepted August 6, 2014.

${ }^{1}$ This article is a corrected version of the article published in the

${ }^{2}$ Corresponding author: Sanjeev.anand@sdstate.edu
} November 2014 issue of Journal of Dairy Science under the same title with the following DOI: http://dx.doi.org/10.3168/jds.20148342. The DOI of this corrected version is http://dx.doi.org/10.3168/ jds.2014-97-12-8009.
\end{abstract}

at $8.2 \%$. Conversely, B. sonorensis made up $12 \%$ of the summer isolates followed by Bacillus pumilus at $10.8 \%$. Bacillus licheniformis is a ubiquitous microbe and was isolated from both TDB and sporeformer categories in all 3 sample types. There were larger increases in $\mathrm{SC}$ than TDB, indicating that summer temperatures and conditions may favor proliferation of sporeforming bacteria over that of TDB. In conclusion, samples from bulk tank milk, milking cluster swabs, and corn silage samples at each of the 10 sites indicated that B. licheniformis was the major contaminant species, regardless of season. In this experiment, corn silage was the major environmental source of both TDB and SC with higher concentrations in summer when compared with winter. Key words: spore, thermoduric bacteria, corn silage, Bacillus

\section{INTRODUCTION}

Food safety has come a long way since the days of drinking warm raw milk, fresh from the udder. While some argue this to be the healthiest and highest quality milk, current food recalls and foodborne illness outbreaks indicate the need for pasteurization. Along with safety, consumers are becoming more readily aware of food quality and insist upon products with the highest standards for excellence. As the population continues to increase, the consumption and demand for high-quality dairy products follows suit. In the United States, the Food and Drug Administration along with the USDA have declared that thermoduric, thermophilic, psychrotrophic, and spore-forming bacteria pose the greatest spoilage threat to dairy products (Hull et al., 1992). Pasteurization is a necessary step for safe consumption of fluid milk and other dairy products (Gleeson et al., 2013), but it does not fully inactivate heat-tolerant microorganisms. Thermoduric bacteria (TDB) have the potential to withstand pasteurization temperatures (Rückert et al., 2004; Gleeson et al., 2013). In addition, some highly heat-resistant spores can survive UHT (Harrington, 2009) and even spray-drying processes and persist in pasteurized powders (Hammer et al., 1995). Similarly, psychrotrophic bacteria have the abil- 
ity to proliferate at refrigeration temperatures (Hull et al., 1992; te Giffel et al., 1995). Contamination in raw milk can arise from a variety of sources including, but not limited to soil (Slaghuis et al., 1997; Vissers et al., 2007a), feed (Hull et al., 1992; Slaghuis et al., 1997; te Giffel et al., 2002), water (Billing and Cuthbert, 1958; Torp et al., 2001), bedding (Hull et al., 1992; Torp et al., 2001; te Giffel et al., 2002), manure (Hull et al., 1992; Van Heddeghem and Vlaemynck, 1992; Fagerlund et al., 2004), teats (Christiansson et al., 1999), and milking equipment (Van Heddeghem and Vlaemynck, 1992; Christiansson et al., 1999; Torp et al., 2001; te Giffel et al., 2002). Spores, specifically, Bacillus species, are commonly present in raw milk (Crielly et al., 1994; Scheldeman et al., 2005), and in farm bulk milk tanks have reached up to $3 \log$ (Vissers et al., 2007b; Scheldeman et al., 2005). Spore concentrations of $3 \mathrm{log}$ have been reported on teat cups and milking clusters (Scheldeman et al., 2005).

The thermoduric sporeformers and their spores can be carried over to dairy products (Lukášová et al., 2001; Hill and Smythe, 2012). They are especially significant in dried products due to the concentration effect. Milk powders are highly lucrative dairy products, because of their ease of transportation and prolonged shelf life compared with fluid milk (Tetra Pak Processing Systems, 2003). Their prolonged shelf life makes them an ideal product for worldwide exports. At the present time, however, there are no international standards set for acceptable spore concentrations in milk powders. A large majority of bacteria recovered from milk powders are classified under the genus Bacillus. In a large study encompassing powders from 18 different countries, $92 \%$ of bacteria isolates recovered were classified as Geobacillus stearothermophilus, Bacillus licheniformis, or Anoxybacillus flavithermus (Scott et al., 2007). These strains are classified as thermophilic bacteria, as they could grow at high temperatures and proliferate during the regeneration sections of the pasteurizer plate and stages of the evaporator during milk processing (Scott et al., 2007). Processing milk into powder concentrates total milk solids as well as any spores or spore-forming bacteria present in the incoming raw milk (Hill and Smythe, 2012). A recent comprehensive review includes the details on aerobic sporeformers and their implications for dairy industry (Anand and Khanal, 2013).

The incidence of spores and TDB in bulk tank milk has been extensively reported in many parts of the world, but none have been recently conducted in the Midwestern United States (Boor et al., 1998; Christiansson et al., 1999; te Giffel et al., 2002; Scheldeman et al., 2005, Magnusson et al., 2006; Coorevits et al., 2008). Magnusson et al. (2006) conducted an extensive study troubleshooting different premilking teat- cleaning procedures to decrease the number of spores in the resultant bulk tank milk. A predictive modeling system created by Vissers et al. (2007b) estimated soil contamination of teats results in $33 \%$ of bulk tank milk containing greater than 1,000 spores $/ \mathrm{mL}$. Another study conducted in New York State found that the mean number of aerobic spores in raw milk supply was around 49 spores $/ \mathrm{mL}$, and the corresponding TDB was enumerated at $129 \mathrm{cfu} / \mathrm{mL}$ (Boor et al., 1998).

The present study comprised 10 dairies ranging from 650 to 3,500 lactating cows located on the eastern part of South Dakota along Interstate 29. This experiment tracked the incidences and sources of TDB and bacterial spore contamination on the 10 local dairies and the raw milk in bulk tanks that supplied milk for the Central Federal Milk Order No. 32 of the central Midwestern United States. Winter and summer samples were tested to assess the variation between both seasons. Environmental samples comprising corn silage and milking cluster swabs were also collected at 9 of the farms to track potential cross contamination into the bulk tank milk. The identity of the dairies remained confidential, but each was identified with a specific number. Each dairy was sampled a total of 3 times both in winter (January-March) and summer (June-August). Generally, no significant differences existed in the husbandry practices between seasons in the farms sampled.

\section{MATERIALS AND METHODS}

\section{Sample Collection}

Two 30-mL milk samples were taken from the bulk tank at each of the 10 sites. Environmental samples obtained from 9 of the 10 sites consisted of Quick Swabs (3M Co., St. Paul, MN) of the milking clusters and corn silage composites taken at 3 different heights of the pile. Raw milk samples were transported to the laboratory refrigerated and kept at $<6^{\circ} \mathrm{C}$, and then plated and incubated within $12 \mathrm{~h}$ of being obtained. Environmental swabs were kept refrigerated and plated within $24 \mathrm{~h}$.

Raw milk samples were split into 2 screw-cap tubes of $5-\mathrm{mL}$ each. Environmental swabs were displaced into 9-mL PBS dilution tubes and then split into two. Samples of $10 \pm 0.5 \mathrm{~g}$ of corn silage were diluted in 90 $\mathrm{mL}$ of PBS and then placed in a stomacher for $2 \mathrm{~min}$ at $260 \mathrm{rpm}$ (te Giffel et al., 2002) and then split in half into screw-cap tubes.

\section{Sample Plating}

Heat treatments for thermoduric bacteria counts (TDC) or laboratory pasteurization counts, and spore 
counts (SC) were $63 \pm 0.5^{\circ} \mathrm{C}$ for $30 \mathrm{~min}$ and $80 \pm 0.5^{\circ} \mathrm{C}$ $($ mean $\pm \mathrm{SE})$ for $10 \mathrm{~min}$, respectively. Sterile $20 \times$ 125-mm screw cap test tubes were used for water bath incubations; the water level was in contact with the entire sample without covering the test tube lid (Wehr and Frank, 2004). Samples were cooled for $10 \mathrm{~min}$ in an ice water bath and then pour plated in duplicate on plate count agar (Remel Inc., Lenexa, KS). Duplicates were incubated at ideal growth temperatures for each group of bacteria: psychrotolerants at $4^{\circ} \mathrm{C}$ for $7 \mathrm{~d}$ and mesophiles and thermophiles for $48 \mathrm{~h}$ at 37 and $55^{\circ} \mathrm{C}$, respectively.

\section{Isolate Identification}

Morphologically different colonies were taken at random from the plates from each sample type and site. A portion of the spore-forming isolates were sent for genetic identification to the Food Safety Laboratory, Cornell University (Ithaca, NY). These isolates were identified by PCR using a portion of the rpo $B$ sequences according to previously documented procedures (Huck et al., 2007). Identifications were based on phylogenetic comparisons of a 635 -bp region of the rpo $B$ gene. Raw sequence data was edited using identified using Sequencher (Gene Codes Co., Ann Arbor, MI). The rest of the isolates were sent to the Animal Disease Research and Diagnostic Laboratory at South Dakota State University (Brookings) to be identified through matrix-assisted laser desorption/ionization and timeof-flight (MALDI-TOF) mass spectrometry (MALDI Biotyper; Bruker Daltonics Inc., Billerica, MA). Colonies were freshly grown overnight at either 37 or $55^{\circ} \mathrm{C}$ on tryptic soy agar (Remel Inc.) infused with $5 \%$ sheep blood or brain-heart infusion agar. Samples sent for MALDI-TOF were freshly grown without refrigeration in order to retain the integrity of cellular proteins. All of the isolate identifications are reported together in the Results and Discussion section.

\section{Statistical Analysis}

Statistical analyses were performed using SAS (SAS Institute Inc., Cary, NC). Microbiological counts were logarithmically transformed before calculating means. Poisson regression with adjustment for overdispersion is used to determine statistical differences between group means.

\section{RESULTS AND DISCUSSION}

\section{Spores}

Spore counts were different between all farms $(P<$ 0.01 ) and between winter and summer. Table 1 breaks SC down into thermophilic and mesophilic, whereas Table 2 compartmentalizes counts for each specific site and between summer and winter sampling periods. Each season was sampled a total of 3 times with 2 raw milk samples pulled from the bulk tank each time. Peak SC for summer was $1.63 \log$ observed at site 2, closely followed by site 3 with $1.55 \mathrm{log}$. The overall average $( \pm \mathrm{SE})$ for the summer was $1.37 \pm 0.06 \mathrm{log}$. All the sites during the summer had SC under 2 log.

Overall SC average $( \pm \mathrm{SE})$ during the winter was much lower at $0.85 \pm 0.08 \mathrm{log}$. There was greater variation during winter, with $\mathrm{SC}$ ranging from $0.30 \mathrm{log}$ (site 3) up to $1.17 \log$ (site 1). The winter SC average was about 1 log lower than during the summer, showing a trend for more spores during the summer.

Corn silage was sampled from 9 out of the 10 sites (site 5 exempt). Table 3 summarizes total SC for winter and summer. Seasons differed with winter SC being much more variable than summer. Maximum SC were $6.85 \log ($ site 10) down to a minimum of $5.74 \log$ (site 3) and an average $( \pm \mathrm{SE})$ of $6.33 \pm 0.11 \mathrm{log}$. Most summer $\mathrm{SC}$ grew at temperatures typical of mesophilic bacteria (6.22 out of $6.33 \mathrm{log}$; Table 1$)$; however, summer thermophilic SC (5.59 log) saw a larger increase compared with winter SC.

Table 1. Mean seasonal variation for mesophilic and thermophilic bacteria

\begin{tabular}{|c|c|c|c|c|c|c|c|}
\hline Sample & $\begin{array}{c}\text { Average } \\
\text { temperature }\left({ }^{\circ} \mathrm{C}\right)\end{array}$ & \multicolumn{3}{|c|}{ Spores } & \multicolumn{3}{|c|}{ Thermoduric bacteria } \\
\hline Winter & -9 & & & & & & \\
\hline Milking cluster $\left(\log \mathrm{cfu} / \mathrm{cm}^{2}\right)$ & & 1.38 & 1.21 & 1.64 & 1.59 & 1.28 & 1.78 \\
\hline Corn silage $(\log \mathrm{cfu} / \mathrm{g})$ & & 3.35 & 2.95 & 3.60 & 3.84 & 3.73 & 4.09 \\
\hline Summer & 30 & & & & & & \\
\hline
\end{tabular}


Table 2. Total spore and thermoduric bacterial counts in raw bulk tank milk samples $(\log \mathrm{cfu} / \mathrm{mL})$

\begin{tabular}{|c|c|c|c|c|}
\hline \multirow[b]{2}{*}{ Site } & \multicolumn{2}{|c|}{ Total spores } & \multicolumn{2}{|c|}{ Total thermoduric bacteria } \\
\hline & Summer $^{1}$ & Winter $^{2}$ & Summer ${ }^{1}$ & Winter $^{2}$ \\
\hline 1 & 1.41 & 1.17 & 2.46 & 2.11 \\
\hline 2 & 1.63 & 1.0 & 2.11 & 2.16 \\
\hline 3 & 1.55 & 0.30 & 1.46 & 1.39 \\
\hline 4 & 1.07 & 0.69 & 1.14 & 2.01 \\
\hline 5 & 1.50 & 0.77 & 1.44 & 1.59 \\
\hline 6 & 1.51 & 0.84 & 1.41 & 1.47 \\
\hline 7 & 1.11 & 0.84 & 2.59 & 2.15 \\
\hline 8 & 1.36 & 1.07 & 1.41 & 2.35 \\
\hline 9 & 1.46 & 1.07 & 2.55 & 1.20 \\
\hline 10 & 1.14 & 0.69 & 2.30 & 1.84 \\
\hline Average $^{3}$ & $1.37 \pm 0.06$ & $0.85 \pm 0.08$ & $1.89 \pm 0.17$ & $1.83 \pm 0.12$ \\
\hline
\end{tabular}

${ }^{1}$ Average of 3 sampling periods with 2 observations each in duplicate (June-August).

${ }^{2}$ Average of 3 sampling periods with 2 observations each in duplicate (January-March).

${ }^{3}$ Mean $( \pm \mathrm{SE})$ of 10 sites.

The SC during winter were almost half those of summer, with an average $( \pm \mathrm{SE})$ of $3.60 \pm 0.29 \mathrm{log}$. Corn silage was stored outside on the farms and very little, if any, bacterial growth would have been supported on the surface at such extreme low temperatures $\left(-9^{\circ} \mathrm{C}\right)$.

Spore concentrations in corn silage samples were higher than previously recorded in the literature (te Giffel et al., 2002; McGuiggan et al., 2002). The current study, however, looked at both mesophilic and thermophilic SC, whereas those other 2 studies focused on mesophilic spores only. Silage sampled in the current study was all stored outside in silage piles covered with a tarp. In the other 2 studies cited, however, silage was kept in concrete silos, which may better preserve the feed compared with a pile method, as less open face exists on top of a silo than on a pile of silage. Although other feedstuffs could have been sampled, corn silage was chosen, as it was fed daily on each farm and made up a substantial portion of the daily ration.
Milking cluster samples differed significantly between sites (Table 4). Summer mesophilic SC at $1.58 \log$ were not different than thermophilic $(1.45 \mathrm{log})$. Site 2 was the only farm with total SC exceeding $2.3 \mathrm{log}$, which may explain why its milk SC at $1.63 \mathrm{log}$ ranked the highest. This is lower than the reported maximum values of up to $3 \mathrm{log}$ SC (Scheldeman et al., 2005).

Winter SC for milking cluster swabs were lower at $1.64 \mathrm{log}$, albeit with much larger variability between sites. Site 2 once again had maximum SC with $2.5 \mathrm{log}$ compared with the minimum $0.47 \log$ for site 3 . This may have resulted from dirty milking clusters used in site 2 parlor, as the SC from the milking clusters at site 2 was the highest (Table 4) The amount of soil on the teats was shown to be a large contributor to higher SC in bulk tank milk (Vissers et al., 2007a). In the current trial, total winter SC were $1.64 \log$ compared with $1.83 \mathrm{log}$ during the summer. This was lower than $\mathrm{SC}$ in previous reports, which averaged 3.0 logs (Vissers et al., 2007b; Scheldeman et al., 2005).

Table 3. Total spore and thermoduric bacterial counts in corn silage samples (log cfu/g)

\begin{tabular}{lccccc}
\hline & \multicolumn{2}{c}{ Total spores } & & \multicolumn{2}{c}{ Total thermoduric bacteria } \\
\cline { 2 - 3 } \cline { 5 - 5 } Site & Summer $^{1}$ & Winter $^{2}$ & & Summer $^{1}$ & Winter $^{2}$ \\
\hline 1 & 6.27 & 3.86 & & 6.18 & 4.42 \\
2 & 6.26 & 2.90 & & 5.27 & 5.25 \\
3 & 5.74 & 3.34 & & 5.95 & 3.12 \\
4 & 6.35 & 3.32 & & 6.04 & 4.20 \\
6 & 6.72 & & & 6.26 & 4.58 \\
7 & 6.35 & 5.09 & & 5.91 & 5.92 \\
8 & 5.94 & 3.42 & & 5.40 & 3.57 \\
9 & 6.46 & 3.09 & & 5.60 & 3.47 \\
10 & 6.85 & $3.60 \pm 0.29$ & & $5.85 \pm 0.11$ & $4.09 \pm 0.29$ \\
Average $^{3}$ & $6.33 \pm 0.11$ & & &
\end{tabular}

${ }^{1}$ Average of 3 sampling periods with 2 observations each in duplicate (June-August).

${ }^{2}$ Average of 3 sampling periods with 2 observations each in duplicate (January-March).

${ }^{3}$ Mean $( \pm \mathrm{SE})$ of 9 sites. 
Table 4. Total spores and thermoduric bacterial counts in milking cluster swabs samples $\left(\log \mathrm{cfu} / \mathrm{cm}^{2}\right)$

\begin{tabular}{lccccc}
\hline & \multicolumn{2}{c}{ Total spores } & & \multicolumn{2}{c}{ Total thermoduric bacteria } \\
\cline { 2 - 3 } \cline { 5 - 5 } Site & Summer $^{1}$ & Winter $^{2}$ & & Summer $^{1}$ & Winter $^{2}$ \\
\hline 1 & 1.3 & 1.27 & & 1.88 & 1.55 \\
2 & 2.37 & 2.5 & & 2.42 & 2.32 \\
3 & 1.53 & 1.49 & & 1.67 & 0.84 \\
4 & 1.59 & 1.79 & & 2.67 & 1.43 \\
6 & 1.98 & 1.41 & & 2.19 & 2.17 \\
7 & 2.06 & 2.92 & & 1.97 & 1.78 \\
8 & 2.11 & 1.83 & & 1.72 & 1.86 \\
9 & 1.90 & $1.64 \pm 0.19$ & & $2.01 \pm 0.11$ & $1.79 \pm 0.15$ \\
10 & $1.83 \pm 0.11$ & & & &
\end{tabular}

${ }^{1}$ Average of 3 sampling periods with 2 observations each in duplicate (June-August).

${ }^{2}$ Average of 3 sampling periods with 2 observations each in duplicate (January-March).

${ }^{3}$ Mean $( \pm \mathrm{SE})$ of 9 sites.

\section{$T D B$}

Bulk milk tank samples had higher TDC compared with SC. During the summer, TDB were composed of more mesophiles $(1.79 \mathrm{log})$ than thermophiles $(0.93 \mathrm{log}$; shown in Table 1), which is good, as they are less likely to survive and regenerate during milk processing (Scott et al., 2007; Gleeson et al., 2013). The average summer TDC was $1.89 \mathrm{log}$, with the highest value at $2.59 \mathrm{log}$ observed on site 7 and the lowest of $1.14 \log$ on site 4 . Variability existed between sites; however, about 5 of the 10 sites had TDC that exceeded 2 log during the summer.

The 10 sites were highly variable in TDC, suggesting that individual cleaning practices may have a substantial effect on the presence of thermoduric bacteria in raw milk. This suggests the need for milk production as well as manufacturing facilities to pay special attention to their cleaning-in-place procedures, especially during the summer months to prevent any potential contamination issues. A previous study statistically followed the correlation between high-quality raw milk and high wash water and efficacy of cleaning chemicals preluded only by teat condition and score (Elmoslemany et al., 2009). Thermoduric thermophiles are of interest specifically, as they can proliferate within segments of the pasteurizer regeneration section and within stages of the evaporator (Scott et al., 2007). Site 7 consistently had higher counts for both winter and summer, indicating a source of contamination or need for better cleaning practices on this particular farm. One plausible explanation may be the presence of a biofilm on milking equipment formed in milk or mineral deposits on cracks or imperfections in the rubber parts of the equipment. Biofilm formation protects viable cells from the effects of sanitation and cleaning-in-place procedures, allowing recontamination as fresh raw milk is obtained (Zottola and Sasahara, 1994; Kumar and Anand, 1998). A possible reason for variability on the farms may be due to cleaning-resistant biofilms leading to inconsistent cross-contamination.

The average TDC in summer corn silage samples was $5.85 \mathrm{log}$ (Table 3). Although this count is high, summer SC actually exceeded TDC in corn silage, the only sample where SC were higher than TDC for either season (Table 1). All silage sampled was stored outside with no protection from the elements. The highest summer TDC were observed on site 6 with $6.26 \log$ compared with site 2 , which had the lowest value at $5.27 \mathrm{log}$. The reason that feed was sampled is because sporeformers have the ability to pass through the gastrointestinal tract and have been isolated in feces and fecal material (Huck et al., 2008), so they can potentially influence the contamination of the milking equipment and bulk tank milk. Although the feed was tested for sporeformers, the fecal matter was not sampled in the current study, but high levels in the feed may potentially correlate with high sporeformers in the feces.

The milking cluster swabs showed seasonal TDC variations and also variations from the 9 specific sites. The average summer TDC was $2.01 \mathrm{log}$, with a peak of $2.67 \log$ occurring on site 6 down to $1.67 \log$ on site 3 . It has been reported that during summer grazing, cow teats have the potential to be more contaminated due to increased exposure to soil in pastures and extended hours spent outside grazing (Christiansson et al., 1999).

Higher TDC on milking equipment may result in higher counts in the bulk milk tank. The nature of the milking cluster places this piece of equipment in direct close contact with individual teats, and has the potential to pick up dirt, soil, bedding, feces, or other contaminants left over after the precleaning process. 
Milking clusters enter in direct contact with raw milk after it leaves the udder and any contaminants present will also be mixed in with the final milk kept in the tank. A study conducted in New York State comprised 855 raw milk samples taken in the winter (December-January) and found an average of $129 \mathrm{cfu} / \mathrm{mL}$ for the laboratory pasteurization counts representative of TDB. The counts were variable among the different sources, ranging from $80 \mathrm{cfu} / \mathrm{mL}(1.90 \mathrm{log})$ up to a maximum of $371 \mathrm{cfu} / \mathrm{mL}$ (2.56 log; Boor et al., 1998). The maximum and mean counts in the current study were at 2.32 and $1.78 \mathrm{log}$, respectively.

\section{Isolates}

Eighty-five isolates were identified in winter samples of milk (59), corn silage (10), and environment (18; Table 5). Eleven different species of bacteria were identified, the predominant ones being as follows: Bacillus licheniformis (62.4\%), Bacillus subtilis (9.4\%), and Bacillus sonorensis $(8.2 \%)$. There was one occurrence of Klebsiella oxytoca isolated from a milking cluster. A less common species identified was Bacillus safensis, and it was found on one milking cluster and consequently also isolated from the milk samples from site 4 . This suggests that contamination arising from milking clusters at this site has the potential of ending up in raw milk. Bacillus cereus was isolated in 2 instances, from milk and milking clusters. This species was also isolated from a milking cluster swab and bulk tank milk, but from different sites, so no strong conclusions can be drawn, except that the organism was present in both samples.

Summer sampling had 83 positive identifications of which $49.4 \%$ were B. licheniformis, $12 \%$ B. sonorensis, and $10.8 \%$ Bacillus pumilus (Table 6 ). Compared with winter (85 isolates), greater diversity existed, with 19 different species identified using MALDI-TOF mass spectrometry, including Klebsiella and Mannheimia

Table 5. Bacteria species identified in winter sampling

\begin{tabular}{lcc}
\hline Winter species & $\begin{array}{c}\text { No. of positive } \\
\text { identifications }\end{array}$ & $\begin{array}{c}\% \text { of } \\
\text { identifications }\end{array}$ \\
\hline Bacillus licheniformis & 53 & 62 \\
Bacillus subtilis & 8 & 9 \\
Bacillus sonorensis & 7 & 8 \\
Bacillus pumilus & 5 & 6 \\
Bacillus safensis & 3 & 4 \\
Thermoactinomyces spp. & 3 & 4 \\
Bacillus cereus & 2 & 2 \\
Other & 4 & 5 \\
Total & 85 & 100
\end{tabular}

${ }^{1}$ Includes Bacillus cereus, Bacillus mycoides, Bacillus smithii, and Brevibacillus borstelensis.
Table 6. Bacteria species identified during the summer sampling

\begin{tabular}{lcc}
\hline Summer species & $\begin{array}{c}\text { No. of positive } \\
\text { identifications }\end{array}$ & $\begin{array}{c}\text { \% of } \\
\text { identifications }\end{array}$ \\
\hline Bacillus licheniformis & 41 & 49 \\
Bacillus sonorensis & 10 & 12 \\
Bacillus pumilus & 9 & 11 \\
Alcaligenes faecalis & 2 & 2 \\
Bacillus altitudinis & 2 & 2 \\
Bacillus subtilis & 2 & 2 \\
Klebsiella pneumoniae & 2 & 2 \\
Klebsiella oxytoca & 2 & 2 \\
Mannheimia haemolytica & 2 & 2 \\
Other & 11 & 13 \\
Total & 83 & 100 \\
\hline
\end{tabular}

${ }^{1}$ Includes Bacillus cereus, Bacillus coagulans, Bacillus mycoides, Bacillus smithii, Bacillus thermoamylovorans, Geobacillus stearothermophilus, Ochrobactrum grignonense, Paenibacillus jamilae, Paenibacillus peoriae, Serratia marcescens, and Streptococcus gallolyticus.

haemolytica, which can cause zoonotic diseases in humans and respiratory diseases in calves (Kehrenberg et al., 2001; Helmick et al., 2013). Klebsiella pneumoniae was isolated from raw milk and corn silage samples, but not from milking clusters. Raw milk bacteria were much more diverse than environmental isolates from milking clusters and corn silage, because the bulk tank is the source for all of the raw milk and any and all contamination from the milking equipment, udders, teats, feed, and so on.

There was distinct seasonal variability between winter and summer samples along with differences between the 10 sites sampled in this study. The incidence of the same bacteria species were tracked from environmental to raw milk samples. The most common species isolated was $B$. licheniformis, both from each of the 3 sample types and both seasons. Bacillus licheniformis has also been identified as a common contaminant of milk powders (Scott et al., 2007). Although B. licheniformis is not a known human pathogen, it is an organism that arises during spoilage and, as with many bacteria high levels, will have adverse effects on milk organoleptic and functional properties (Crielly et al., 1994).

\section{CONCLUSIONS}

The higher incidence of thermophiles during summer, both for thermoduric and spore-forming bacteria is of concern. This is something that needs to be addressed at the manufacturing plant level, as seasonal changes on farm cannot be avoided. Better cleaning procedures need to be implemented during the summer to not allow for more bacterial growth heightening the contamination risk into raw milk during the season. Seasonal changes must be kept in mind when processing milk, as they have large effect on the bacterial microflora 
present in raw milk. Thermophilic, thermoduric, and spore-forming bacteria have the ability to contaminate products postpasteurization. However, if their numbers can be reduced before pasteurization, it would reduce the risk in pasteurized dairy products. Contamination can occur at any level; however, seasonal changes in bacteria influence the potential risk factors in the final dairy products and should be studied more extensively. More studies of this nature need to be conducted on a larger scale in different regions of the country. A comprehensive study encompassing the entire United States would be helpful to obtain comprehensive data and provide an overall picture of the thermoduric bacterial populations present on dairy farms.

\section{ACKNOWLEDGMENTS}

The authors thank Cornell University (Ithaca, NY) for molecular identification, and Seema Das (South Dakota State University, Brookings) for her assistance in identifying the bacterial isolates using MALDI-TOF. This work was funded by Dairy Management Inc. (Rosemont, IL) and administered by the Dairy Research Institute (DRI). The authors also acknowledge the support of the Agricultural Experiment Station (South Dakota State University) in conducting the study.

\section{REFERENCES}

Anand, S., and S. N. Khanal. 2013. Significance of aerobic sporeformers in milk and dairy products: A review. US Dairy Export Council, Arlington, VA.

Billing, E., and W. A. Cuthbert. 1958. Bitty cream: The occurrence and significance of Bacillus cereus in raw milk supplies. J. Appl. Bacteriol. 21:65-78.

Boor, K. J., D. P. Brown, S. C. Murphy, S. M. Kozlowski, and D. K. Bandler. 1998. Microbiological and chemical quality of raw milk in New York State. J. Dairy Sci. 81:1743-1748.

Christiansson, A., J. Bertilsson, and B. Svensson. 1999. Bacillus cereus spores in raw milk: Factors affecting the contamination of milk during the grazing period. J. Dairy Sci. 82:305-314.

Coorevits, A., V. De Jonghe, J. Vandroemme, R. Reekmans, J. Heyrman, W. Messens, P. De Vos, and M. Heyndrickx. 2008. Comparative analysis of the diversity of aerobic spore- forming bacteria in raw milk from organic and conventional dairy farms. Syst. Appl. Microbiol. 31:126-140.

Crielly, E. M., N. A. Logan, and A. Anderton. 1994. Studies on the Bacillus flora of milk and milk products. J. Appl. Bacteriol. $77: 256-263$.

Elmoslemany, A. M., G. P. Keefe, I. R. Dohoo, and B. M. Jayarao. 2009. Risk factors for bacteriological quality of bulk tank milk in Prince Edward Island dairy herds. Part 2: Bacteria count specific risk factors. J. Dairy Sci. 92:2644-2652.

Fagerlund, A., O. Ween, T. Lund, S. P. Hardy, and P. E. Granum. 2004. Genetic and functional analysis of the cytK family of genes in Bacillus cereus. Microbiology 150:2689-2697.

Gleeson, D., A. O'Connell, and K. Jordan. 2013. Review of potential sources and control of thermoduric bacteria in bulk-tank milk. Ir. J. Agric. Food Res. 52:217-227.

Hammer, P., F. Lembke, G. Suhren, and W. Heeschen. 1995. Characterization of a heat resistant mesophilic Bacillus species affect- ing quality of UHT-milk-A preliminary report. Kiel. Milchwirtschaftliche Forschungsberichte 47:297-305.

Harrington R. 2009. Asia and UHT milk to lead strong growth in aseptic packaging. Food Production Daily. Accessed Apr. 2014. http://www.foodproductiondaily.com/Packaging/Asia-and-UHTmilk-to-lead-strong-growth-in-aseptic-packaging.

Helmick, K., A. Guthrie, and A. Mutlow. 2013. Klebsiella. American Association of Zoo Veterinarians Infectious Disease Committee Manual. American Association of Zoo Veterinarians, Yulee, FL.

Hill, B. M., and B. W. Smythe. 2012. Endospores of thermophilic bacteria in ingredient milk powders and their significance to the manufacture of sterilized milk products: An industrial perspective. Food Rev. Int. 28:299-312.

Huck, J. R., M. Sonnen, and K. J. Boor. 2008. Tracking heat-resistant cold-thriving fluid milk spoilage bacteria from farm to packaged product. J. Dairy Sci. 91:1218-1228.

Huck, J. R., N. H. Woodcock, R. D. Ralyea, and K. J. Boor. 2007. Molecular subtyping and characterization of psychrotolerant endospore-forming bacteria in two New York State fluid milk processing systems. J. Food Prot. 70:2354-2364.

Hull, R. R., S. Toyne, I. N. Haynes, and F. L. Lehmann. 1992. Thermoduric bacteria: A re-emerging problem in cheesemaking. Aust. J. Dairy Technol. 47:91-94.

Kehrenberg, C., S. A. Salmon, J. L. Watts, and S. Schwarz. 2001. Tetracycline resistance genes in isolates of Pasteurella multocida, Mannheimia haemolytica, Mannheimia glucosida and Mannheimia varigena from bovine and swine respiratory disease: Intergeneric spread of the tet $(\mathrm{H})$ plasmid pMHT1. J. Antimicrob. Chemother. 48:631-640.

Kumar, C. G., and S. K. Anand. 1998. Significance of microbial biofilms in food industry: A review. Int. J. Food Microbiol. 42:9-27.

Lukášová, J., J. Vyhnálková, and Z. Páčová. 2001. Bacillus species in raw milk and in the farm environment. Milchwissenschaft 56:609611

Magnusson, M., A. Christiansson, B. Svensson, and C. Kolstrup. 2006. Effect of different premilking manual teat cleaning methods on bacterial spores in milk. J. Dairy Sci. 89:3866-3875.

McGuiggan, J. T. M., D. R. McCleery, A. Hannan, and A. Gilmour. 2002. Aerobic spore-forming bacteria in bulk raw milk: Factors influencing the numbers of psychrotrophic, mesophilic and thermophilic Bacillus spores. Int. J. Dairy Technol. 55:100-107.

Rückert, A., R. S. Ronimus, and H. W. Morgan. 2004. A RAPD-based survey of thermophilic bacilli in milk powders from different countries. Int. J. Food Microbiol. 96:263-272.

Scheldeman, P.. A. Pil, L. Herman, P. De Vos, and M. Heyndrickx. 2005. Incidence and diversity of potentially highly heat-resistant spores isolated at dairy farms. Appl. Environ. Microbiol. 71:1480-1494

Scott, S. A., J. D. Brooks, J. Rakonjac, K. M. R. Walker, and S. H. Flint. 2007. The formation of thermophilic spores during the manufacture of whole milk powder. Int. J. Dairy Technol. 60:109-117.

Slaghuis, B. A., M. C. te Giffel, R. R. Beumer, and G. André. 1997. Effect of pasturing on the incidence of Bacillus cereus spores in raw milk. Int. Dairy J. 7:201-205.

te Giffel, M. C., R. R. Beumer, B. A. Slaghuis, and F. M. Rombouts. 1995. Occurrence and characterization of (physchrotrophic) $\mathrm{Ba}$ cillus cereus on farms in the Netherlands. Neth. Milk Dairy J. 49:125-138.

te Giffel, M. C., A. Wagendorp, A. Herrewegh, and F. Driehuis. 2002. Bacterial spores in silage and raw milk. Antonie van Leeuwenhoek 81:625-630.

Tetra Pak Processing Systems. 2003. Milk and whey powder. Pages 375-388 in Dairy Processing Handbook. 2nd ed. Tetra Pak Processing Systems AB, Lund, Sweden.

Torp, M., G. Holstad, and P. E. Granum. 2001. Bacillus cereus-Feeds and feces as major contamination sources in milk on a dairy farm. Norsk Veterinærtidsskrift 113:462-466

Van Heddeghem, A., and G. Vlaemynck. 1992. Sources of contamination of milk with $B$. cereus on the farm and in the factory. IDF Bull. 275:19-22. Int. Dairy Fed., Brussels, Belgium. 
Vissers, M. M. M, F. Driehuis, M. C. Te Giffel, P. De Jong, and J. M G. Lankveld. 2007a. Concentrations of butyric acid bacteria spores in silage and relationships with aerobic deterioration. J. Dairy Sci. 90:928-936.

Vissers, M. M. M, F. Driehuis, M. C. Te Giffel, P. De Jong, and J. M. G. Lankveld. 2007b. Minimizing the level of butyric acid bacteria spores in farm tank milk. J. Dairy Sci. 90:3278-3285.
Wehr, H. M., and J. Frank. 2004. Standard Methods for the Examination of Dairy Products. 17th ed. American Public Health Association, Washington, DC.

Zottola, E. A., and K. C. Sasahara. 1994. Microbial biofilms in the food processing industry-Should they be a concern? Int. J. Food Microbiol. 23:125-148. 